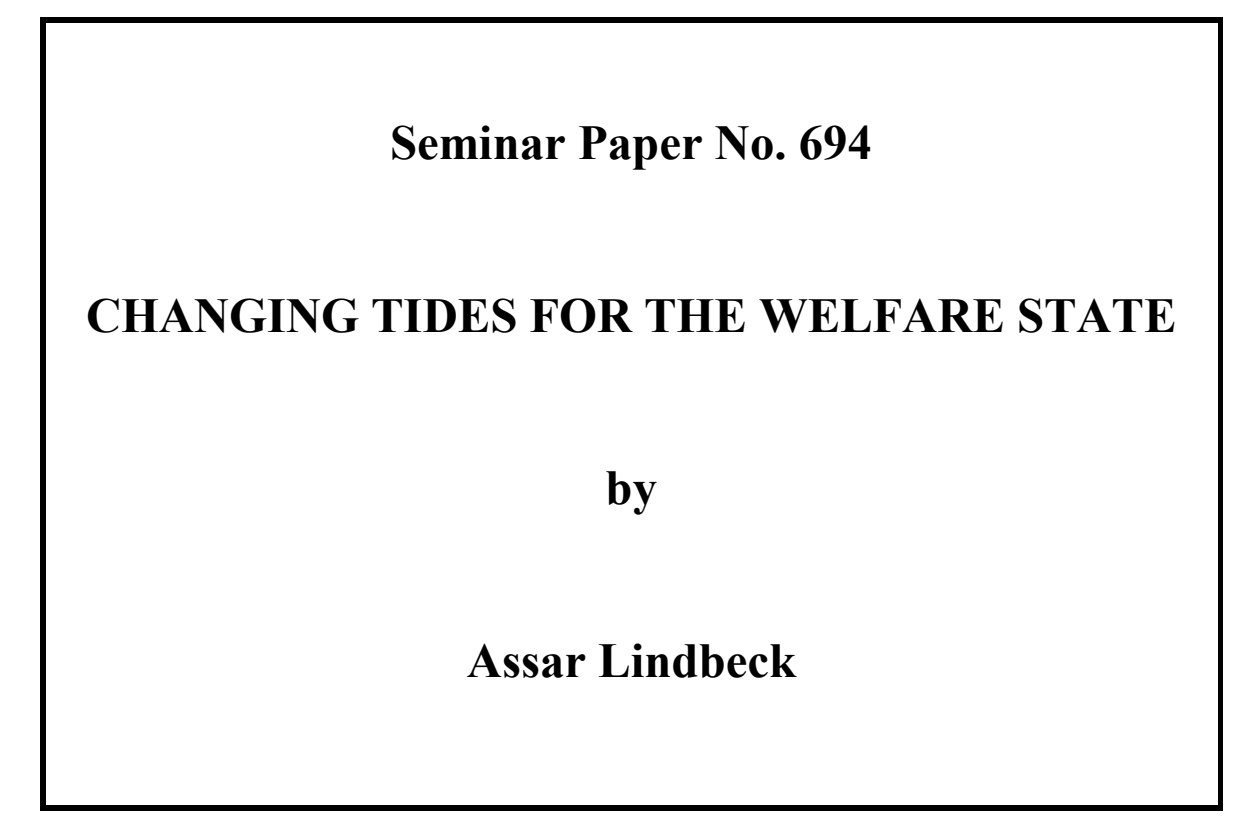

Assar Lindbeck

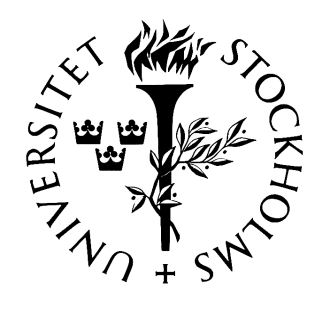

INSTITUTE FOR INTERNATIONAL ECONOMIC STUDIES Stockholm University 
Seminar Paper No. 694

CHANGING TIDES FOR THE WELFARE STATE

by

Assar Lindbeck

Papers in the seminar series are also published on internet in Adobe Acrobat (PDF) format.

Download from http://www.iies.su.se/

Seminar Papers are preliminary material circulated to stimulate discussion and critical comment.

July 2001

Institute for International Economic Studies

S-106 91 Stockholm

Sweden 
$27 / 7,2001$

Assar Lindbeck:

\title{
CHANGING TIDES FOR THE WELFARE STATE \\ - An Essay -
}

\begin{abstract}
:
Socioeconomic conditions and values have changed considerably since the emergence of elaborate welfare-state arrangements during the first decades after World War II. For instance, recent socioeconomic changes have created new needs (justifications) for intertemporal reallocations of income as well as for protection against new types of income risks. Some socioeconomic changes have also undermined the financial viability of a number of traditional welfare-state arrangements. This paper emphasizes developments in the labor market and changes in the structure and preferences of the family. A number of alternative welfare-state reforms are considered in the paper.
\end{abstract}

JEL Classification codes: H00, H4, H5

Keywords: welfare state, changes in labor market, changes in family structure

\footnotetext{
* I am grateful to Jon Dutrieux Anderson, Alessandra Bonfiglioli and Christina Håkansson for help in collecting data. Anders Björklund, Peter Heller, Richard Musgrave and Solveig Wikström provided useful comments on a draft of the paper. I am also grateful for comments from two anonymous referees.
} 
The welfare state is an inheritance from political responses to changes in socioeconomic conditions and values in the past. But the situation today is very different from that which prevailed when the welfare state was constructed. Still, it has turned out to be difficult to adjust welfare-state arrangements to new circumstances. The ensuing misalignment between the welfare state and contemporary conditions does not mean that today's welfare-state arrangements have become obsolete or that voters have turned their backs on the welfare state. According to opinion polls, the welfare state is still quite popular, even though there are specific complaints and popular support for some narrowly targeted welfare-state programs is often rather weak (Taylor-Gooby, 1996; Boeri, Börsch-Supan and Tabellini, 2000). But as we shall see, new socioeconomic developments and changes in values help explain why proposals for welfare-state reform abound and why some such reforms have already been initiated in a number of countries. These are the issues focused on in this essay.

The socioeconomic background of the welfare state is well known. Industrialization meant that periods of work and non-work became more discrete and more random events than before (Piore, 1987; Atkinson, 1991). The resulting temporal desynchronization of an individual's consumption requirements and actual income flows created a need (justification) for new arrangements to reallocate income over his life cycle and to protect him against income risks. At the same time, urbanization reduced the family's ability to satisfy these needs, partly because family members of different generations often became separated geographically. It is also well known that voluntary market solutions could not live up to these new needs because of myopic behavior and free riding of some individuals, and because familiar limitations in private insurance markets as a result of adverse selection, cream skimming, and moral hazard. Nor could the family alone satisfy the increased need for education and health care in industrial and urban societies. All this, of course, is the background for the (reasonable) assertion that the welfare state can be justified not only on distributional (social) grounds but also with reference to efficiency aspects (Barr, 1992). Moreover, we may speculate that destitution among minorities became less socially acceptable during the course of the $20^{\text {th }}$ century. In this sense, social (political) preferences gradually changed, perhaps to some extent as a result of higher income and more widespread education. Meanwhile, we may quarrel about whether social preferences of this type reflect altruism or "enlightened self-interest".

Macroeconomic instability in an industrial society, not least the depression in the 1930s, highlighted the need for income protection. Moreover, rapid economic growth during the first decades after World War II created the economic resources necessary to satisfy these needs to a considerable degree. Indeed, during these decades, welfare-state arrangements in 
many developed countries were gradually transformed from poverty relief and basic (“minimum") income support into broad income-maintenance programs and further expansion of tax-financed services in education and health. A number of socioeconomic features during the early postwar decades also contributed to making the welfare state both financially viable and reasonably well adjusted to the new needs. These features include a rather homogeneous labor force, full employment (mainly for men), quite stable families and favorable demography (a large fraction of the population of working age).

General franchise provided political channels through which the new needs could gradually be translated into concrete action, even though embryos of welfare-state arrangements already existed. By the time the modern welfare state was basically completed in the 1970s, it was mainly adapted to the needs of "standard" families with a male breadwinner and a housewife, though it also provided special arrangements to mitigate poverty for individuals and families without a regularly employed income earner. In several countries in Western Europe, job-protection legislation was added, in particular in the 1970s, as a complement to or a substitute for unemployment benefits and social assistance.

It is well known, however, that socioeconomic changes in recent decades have created new needs (justifications) for intertemporal reallocation of income and protection against new types of income risk. These changes have also generated new service needs that are not well met by traditional welfare-state arrangements. Some socioeconomic changes have also undermined the financial viability of a number of traditional welfare-state arrangements. As in the case of industrialization and urbanization a century ago, the most important changes have taken place in the labor market and the family.

Several driving forces behind these developments may be regarded as exogenous from the point of view of the welfare state. Obvious examples are new technologies, advances in medicine and increased international economic integration. Other driving forces - including changes in demography, work, cohabitation patterns, the life cycle of individuals and macroeconomic developments - are most realistically regarded as combined results of exogenous events and endogenous behavioral adjustments of individuals in response to the welfare state itself, including tax- and benefit-induced distortions of economic incentives. I will also argue that the views ("philosophies") among voters and politicians regarding the relation between the individual and the state have changed in recent decades. Important examples are new ways of viewing an individual's responsibility for his own destiny and his right and ability to exert free choice among alternative types of income protection and social services.

In some countries, the dynamics of the political process may also have generated an "overshooting" of the welfare state, in the sense that voters would have chosen smaller 
aggregate welfare-state spending if incentives for political action had been more symmetric between beneficiaries and taxpayers. As argued by many observers (e. g., Olson, 1965 and Tullock, 1959), since benefits are often selective while taxes are usually general, the incentives of individuals belonging to special interest groups to exert political pressure for new favors are often stronger than the incentives of the general taxpayer to resist such favors. The recursive and incremental nature of the political decision-making process may accentuate this tendency, since different spending programs are seldom weighted against each other simultaneously (Lindbeck, 1985 and 1994). Additions to welfare-state arrangements also create new interest groups for welfare-state spending. Indeed, in societies where a majority of the electorate get the bulk of their income from the government - via benefits or public-sector employment - the interest in large welfare-state spending becomes solidly anchored among a majority of voters; Sweden is one example (Lindbeck 1997b, pp. 1279, 1315).

When discussing these issues, it is important to keep in mind that economic behavior is influenced not only by economic incentives but also by values including social norms and individual ethics (internalized norms). In particular, norms inherited from the past may constrain the (dis)incentive effects in the short run. In a long-term perspective, however, these norms themselves may adjust in response to changes in economic incentives (Lindbeck, 1995). If this hypothesis is correct, the (dis)incentive effects of welfare-state arrangements, and their financing, would in some cases be stronger in the long run than in a short- and medium-term perspective. Such behavioral inertia may accentuate the earlier mentioned tendency to "overshoot" aggregate welfare-state spending since it is difficult for policymakers and voters to predict induced long-term changes in social norms when new welfare-state programs are launched.

These new developments constitute the background for this essay on "changing tides" for the welfare state. It is then important to note that the "welfare regimes" differ considerably among developed countries, with different relative roles of the state, the family and the market for economic security and personal services. I begin by discussing changes in the labor market (section 1). Next, I deal with changes in the structure and stability of the family (section 2). I then turn to contemporary changes in the macroeconomy with important consequences for the functioning of the welfare state (section 3). Here, I deal with three macroeconomic features - short-term macroeconomic instability, economic growth and the internationalization of national economies. Some concluding remarks are offered in section 4. 


\section{Structural Changes in the Labor Market}

\subsection{Labor supply}

What then are the most important examples of "changing tides" in the labor market from the point of view of the welfare state? With respect to labor supply, it is a commonplace that the aging of the population - a combined result of the baby boom in the 1940s, low birth rates since the 1970s and increasing longevity after retirement - threatens the financial viability of the welfare state, in particular the pension system. Indeed, birth rates in most European countries today are considerably below the reproduction level. The average birth rate in Western Europe (the number of children born divided by the average number of women in fertile cohorts) was only 1.47 in 1998 (U.S. Bureau of the Census). Life expectancy at age 65 in Western Europe has increased by slightly more than one year per decade after World War II, ranging from somewhat less than one year per decade in the Netherlands to more than 1.5 year per decade in France (United Nations Demographic Yearbook, 1949, 1960 and 1997). Instead of 45-50 years of work and 5-10 years of retirement half a century ago, a typical young individual today can expect to work for 30-35 years and be retired for about 17 years (OECD, 1998).

Most likely, the fall in birth rates is related to higher costs of raising children (reflecting higher real wages) and the increased labor-force participation of females (Becker, 1981). Some welfare-state arrangements have also contributed to the fall in birth rates since it is no longer essential to have children in order to be supported in old age; pay-go pension systems, for instance, imply that the children of other families support me when I grow old. Government subsidies to education have also delayed the entry of individuals into the labor force. This has reduced the number of taxpayers, though the related accumulation of human capital per individual, and hence increased labor productivity, have counteracted (or even reversed) the negative effects on the tax base.

Since the demographic problems are about the same in most countries in Western Europe, attempts to mitigate these problems via immigration of young and low middle-age workers would have to rely on immigrants from Eastern Europe and non-European countries. Although such immigration certainly makes sense from an economic point of view, we know from experience that ethnic conflicts may be triggered if the size or speed of immigration exceeds certain (hitherto unknown) limits. This is particularly likely to occur if immigration is thought to result in downward pressure on the wages of low-skilled workers or upward pressure on social-assistance spending. Such developments would also complicate the

\footnotetext{
${ }^{1}$ According to projections by the EU Secretariat, the pension rules in effect in the early 1990s imply that the average age-dependency ratio (the number of retirees relative to the number of individuals of working age) will increase by 50 percent between the mid-1990s and 2020 in the EU area (European Community, 1994).
} 
ambitions of welfare states to mitigate segregation and promote social accord. A likely future strategy of governments to deal with this issue would be to favor the immigration of skilled rather than unskilled workers.

Welfare-state arrangements have also contributed a growing number of pensioners, not only via a lower statutory retirement age and more generous subsidies to early retirement but also through subsidized health care, which is likely to have contributed to the rise in longevity. Moreover, government spending on pensions has been boosted by a tendency among politicians to add gradually new types of benefits to existing pension systems, for instance, by successively allotting pension rights for compulsory military service, unemployment periods, the care of children, etc. These new commitments have given rise to unavoidable cost increases associated with the gradual "maturing" of pay-go pensions systems.

Since better health among elderly citizens usually enhances their ability to work, it may not be too far-fetched to alleviate the financial difficulties of the pension system by raising the age of mandatory retirement (the "statutory" retirement age) and reducing subsidies to early retirement. As an illustration of the potential importance of such reforms, in the late 1990s, average labor-force participation in the EU in the 55-65 age group was only about 40 percent, ranging from 24 percent in Belgium to 88 percent in Iceland (OECD, 1999).

References to the political power of retirees and cohorts close to retirement probably do not suffice to explain why it seems so difficult to restrain mandatory pension spending by cuts in pension benefits, increases in the statutory retirement age and reduction in subsidies to early retirement. For instance, some young and middle-aged individuals may be pleased with the idea of not having to support their parents individually in the future. Moreover, with today's incentive structure in favor of early retirement, it is not surprising that rather young cohorts look forward to early retirement themselves, often at no later than 60 - at least this is what opinion polls tell us. Moreover, in all West European countries, unions and firms use early retirement, at the taxpayers' expense, as a way of cutting the work force in individual firms (when this is regarded as necessary) at the lowest possible cost to firms. A common argument is that this reduces aggregate unemployment, which might be true in a short-term perspective.

Considering the wide variability in the capacity and willingness to work among the elderly, there is a strong case for combining the removal of subsidies to early retirement with a more flexible retirement age (possibly with actuarial adjustments of yearly pensions). Elderly workers in poor health could then be referred to the sick or disability insurance system rather than to the pension system. Another, possibly complementary reform could be 
to allow the elderly to continue to work after receiving a pension (without it being reduced), hence partly separating retirement and pension. Indeed, this is rather common in Japan, where employees are often able to continue working at reduced wages after receiving pensions either by performing new tasks in the same firm or by shifting to other firms.

We know that many countries also contemplate more far-reaching reforms of their pension systems, either within the context of existing pay-go systems or by partial or total shifts to fully funded, actuarially fair pension systems. These reforms have usually been designed not only to improve the financial stability of the pension system, but also to induce individuals to take greater responsibility for their future pensions. Indeed, some countries have already implemented such reforms. (I return to this issue in section 2.3 about "individual responsibility".)

Besides these demographic developments, the most important change on the laborsupply side is presumably the rise in labor-force participation of women. The EU average of labor-force participation among adult females (age 15-64) has increased from 42 percent in 1960 to 58 percent today, ranging from 44 percent in Italy to 75 percent in Denmark (OECD, Historical Statistics, 1960-1995; Eurostat, 1998a). The background is well known: rationalization of household work, improved education of women relative to men, fewer children per family and probably also increased preferences among females for economic and social independence.

By boosting the tax base, increased labor-force participation of females obviously helps finance the welfare state. But it also increases the political pressure for welfare-state spending aimed at helping individuals, mostly women, to combine family life and working life. Indeed, there is an obvious possibility of "mutual causation" between female labor-force participation and voting behavior regarding the size and composition of government spending. There is strong empirical evidence that working women tend to vote for parties that favor high government spending in the social sphere, including child care, health care and old age care (Edlund and Pande, 2001). Females are also employed proportionally more than males in the production of government subsidized services, which means that they also have an interest as employees in voting for parties that support government subsidies of this type.

So far, however, only a few countries have adjusted their welfare-state arrangements to the new the situation with rising labor-force participation of women (OECD, 1998). The

\footnotetext{
${ }^{2}$ It is true that some factors have operated in the opposite direction, hence discouraging female labor-force participation. In particular, do-it-yourself tasks have been stimulated by a gradual increase in the relative price of purchased household services. Moreover, in the same way as tariffs favor autarky rather than international trade for a nation, income and consumption taxes favor autarky for the household (do-it-yourself work) rather than purchases of services in the open market (Lindbeck, 1988). Evidently, in the case of females, these two negative effects on labor-force participation have been overridden by the above-mentioned positive effects (in contrast to the case of males).
} 
Nordic countries are an exception, where such labor force participation has, in fact, been systematically stimulated by welfare-state arrangements, including elaborate systems of income transfers to families during parental leave and generous subsidies to child care and old-age care outside the family.

The rise in female labor-force participation, of course, is an important explanation for the increase in part-time work, which is a rather natural arrangement among adults with small children. Indeed, part-time work averages about 17 percent of total employment in Western Europe, ranging from 6 percent in Greece to 39 percent in the Netherlands (Eurostat, 1998b; OECD, 1998). But existing benefit rules are often not well adjusted to part-time work. An illustration is that welfare-state benefits are often reduced if one of the adults in a family decides to work longer hours outside the household.

\subsection{Labor demand}

Some recent and expected changes on the labor-demand side also have important consequences for the functioning of the welfare state. For instance, is there any guarantee that future pension reforms, designed to boost the labor supply of elderly workers (in the age group 55-70), will actually raise employment rather than boosting unemployment for such workers? Economists typically react to this question by suggesting policies that encourage lower relative wage rates or reduced payroll taxes for this group of workers. The first alternative is not easy to implement in the context of collective bargaining because incumbent workers, "insiders", who often dominate union policies, may regard such wage adjustments as underbidding of prevailing wages. As an alternative, the government may encourage elderly workers to sign individual wage contracts, for instance, by no longer favoring collective bargaining contracts. But insiders may be able to resist this as well. First, they may have sufficient political clout to prevent such legislation from the outset. Second, they often have market powers to prevent individuals from underbidding wages and firms from encouraging such underbidding. This may be achieved by threatening to harass potential underbidders or by refusing to cooperate with them in the production process (Lindbeck and Snower, 1988). Lower payroll taxes for elderly workers are perhaps a more realistic alternative than lower relative wages as a way of boosting labor demand for this group. But insiders might use their political powers to resist such policies as well.

In a similar vein, how can we prevent increased labor supply of women from resulting in higher unemployment either for this specific group, or for men who feel the pinch of increased competition from more able females? In the United States, this problem has been solved by the invisible hand, mainly in the market for private services, whereby the demand for female labor has expanded and relative wages of unskilled males have fallen. In the 
Nordic countries, a corresponding increase in labor demand for women has been brought about via the visible hand of increased government service production. Both "hands" have thus far been tied on the European continent.

Moreover, it is rather generally agreed that the widening of the dispersion of earnings, particularly, in the United States and the United Kingdom in the 1980s and early 1990s, and the widening of the distribution of unemployment (in percentage points) in many countries in Western Europe, are largely due to changes in the composition of labor demand in favor of high-skilled workers. Although some observers have referred to increased international competition for labor-intensive products, the most generally accepted explanation is certainly that during this period, Tinbergen's (1975) celebrated "race between technology and education" was won by the former. Dennis Snower and I (Lindbeck and Snower, 1996) have emphasized a third explanation, namely that the well-documented, ongoing reorganization of firms, including the decentralization of authority and initiatives, has favored the demand for versatile workers, i.e., individuals who are able to face up to increased responsibility (often due to idiosyncratic characteristics). This explanation is consistent with the observation that wage dispersion has recently increased also within narrowly defined educational groups, professions and job categories.

This development tends to make centralized wage bargaining relatively less attractive to firms, since the reorganization of work increases job heterogeneity and, as a result, also the heterogeneity of the labor force. It thus becomes more difficult than before to acquire appropriate information about job characteristics on the central level and hence to set appropriate wages from an efficiency point of view. Since centralized wage bargaining often results in a squeeze of wage differentials, shifts to more decentralized bargaining - a likely outcome of the reorganization of work - are likely to accentuate the tendencies toward wider wage dispersion (Lindbeck and Snower, 2001a). However, since relative wages would then be better adjusted to the composition of demand and supply of various types of labor (more "market-conforming" wages), tendencies toward a wider dispersion of job opportunities and unemployment are likely to be mitigated.

Recent changes in types of labor-market contracts have also contributed to more heterogeneity in the labor market. Nowadays, there is a bewildering mixture of permanent ("indefinite") work contracts, fixed-period (temporary) work, project work, bonus systems,

\footnotetext{
${ }^{3}$ There are now systematic empirical studies showing that this type of reorganization of firms is a widespread phenomenon; for a survey of the empirical literature, see Lindbeck and Snower (2001a). A hard-line believer in the technological explanation might be tempted to argue that the reorganization of firms is simply a subset of technological change. Even with that terminology, an explanation in terms of reorganization of work would still be of interest in clarifying what type of technological change is behind the recent widening of the dispersion of earnings and job opportunities. This explanation then emphasizes the role of versatility rather than just technical skills.
} 
stock options, etc. For instance, whereas few workers were on fixed-term contracts in Western Europe during the first decades after World War II, the current EU average is 13 percent, with the highest figure for Spain, 33 percent (Eurostat, 1998a). By allowing fixedterm contracts, the hiring of outsiders is likely to be boosted in business upswings. However, as pointed out by Bentolila and Bertola (1990), temporarily employed workers also function as an "employment buffer" for insiders, which further strengthens their job security and market power.

There is no doubt that these developments in the labor market complicate the egalitarian ambitions of the welfare state. So far, however, in countries with elaborate welfare-state arrangements, the dispersion of the distribution of disposable income has increased considerably less than the distribution of earnings (Gottschalk and Smeeding, 2000; Atkinson, 1999b, 2000). On this count, the welfare states in Western Europe have had some success in counteracting tendencies toward a wider dispersion of income.

The standard policy prescription to counteract tendencies toward a wider dispersion of wages has been to stimulate education and training. It is not obvious, however, that general educational subsidies (to all income groups) will have this effect. For instance, it has been argued by Hassler, Rodriguez More and Zeira (2001) that such subsidies tend to stimulate education among the well-to-do more than among other groups, since the former devote more resources than others to education. By contrast, Nickell and Bell (1997) have hypothesized that a rise in the general level of education enhances individuals' ability to adjust to changes in the composition of labor demand in favor of high skills, and that this will mitigate tendencies toward higher relative wages for high-skill workers. The notion that better education also makes workers more versatile would further mitigate tendencies toward a wider dispersion of wages as a result of the reorganization of work. However, to the extent that versatility depends on an innate idiosyncratic ability to accept responsibility, take initiative and cooperate with others, education and training will not be sufficient to prevent a widening of the dispersion of earnings and job opportunities inherent in the contemporary reorganization of work within firms.

Selective education subsidies to low-skilled workers, or potentially low-skilled workers, are more likely to reduce wage differentials. Such subsidies would also stimulate social mobility, thereby enhancing equality of opportunity, in the sense that some previously low-skilled workers would become high-skilled. The long-term effect of selective education subsidies on social mobility is a more complex matter. While mobility is stimulated by greater economic resources for investment in education among families with low factor 
income, this effect is counteracted by a negative disincentive effect on education due to smaller wage differences (Hassler et al., 2001).

\subsection{The unemployment experience}

It is well known that during the last quarter of the $20^{\text {th }}$ century, Western Europe has been less successful in promoting full employment than in mitigating tendencies toward a wider dispersion of disposable income - presumably in part because of its highly institutionalized, centralized and regulated system of wage formation, which could be expected to constrain relative wage flexibility. Lower employment rates have then not only contributed to undermining the welfare state financially; the insider-outsider divide in society has also sharpened - contrary to the idea that the welfare state should enhance social integration.

Moreover, while traditional welfare-state arrangements provide pensioners with adequate protection against income risks, such risks have instead begun to increase for young and elderly workers and their families - reflected in high unemployment among the former and dropout from the labor force among the latter (partly via early retirement). During the last two decades of the $20^{\text {th }}$ century, the youth unemployment rate (individuals in the age group 15-24) has typically been about 15-20 percent in most of Western Europe. Exceptions are countries with well-developed apprentice systems, such as Austria, Germany and Switzerland, where the rate has oscillated between 5 and 10 percent. Spain and Italy are extreme cases in the opposite direction; their rates have recently hovered in the interval of 2030 percent. As mentioned earlier, employment rates for older workers (aged 55-64 years old) have become as low as 40 percent in the EU as a whole (OECD, 1999).

The reverse causation, from the welfare state to unemployment, is a more controversial issue. It is unavoidable that both equilibrium unemployment (the natural rate or NAIRU) and unemployment persistence (prolonged deviations from the equilibrium rate) may be accentuated by certain types of welfare-state arrangements. Obvious examples are high subsidies of non-work, such as generous and long-lasting unemployment benefits, social assistance ("welfare" in US terminology) for unemployed workers without work requirements, and poverty traps created by with means-tested benefits. There are certainly strong ethical (distributional) justifications for such benefits. But the more generous the benefits and the longer they may be kept, the greater the risk that they reduce active job search and job acceptance, in particular when administration is lax - a well-known example

\footnotetext{
${ }^{4}$ Long ago, Alva and Gunnar Myrdal (1934) argued that a broadening of educational opportunities would ultimately result in genetic sorting on income classes, and that this would subsequently harm the genetic pool among low-income classes and, as a result, slow down social mobility.
} 
of moral hazard. Sufficiently generous subsidies of non-work may also raise the wage costs for low-skilled workers by boosting the reservation wage, with similar unemployment consequences as in the case of (sufficiently high) minimum wages. These general comments are not very controversial. What is controversial is the quantitative importance of these employment effects, and hence the intensity of the conflict between ambitions to provide income support in connection with non-work and a desire to fight long-term unemployment.

The consequences of job-security legislation are an even more complex issue, since such legislation increases the costs of both hiring and firing workers, with ambiguous direct effects on the average unemployment rate over the business cycle. But this is not the end of the story. Since the market power of "insiders" in the labor market is augmented by such legislation, wages are boosted and the demand for workers reduced. If these negative indirect effects on labor demand are sufficiently strong, the average unemployment rate over the business cycle would increase even if the direct effects are not negative, or even positive (Lindbeck and Snower, 2001b). Other types of legislation which enhances the bargaining power of unions will accentuate these effects - for instance, laws and regulations that extend collective agreements to non-union workers and non-union firms, and that facilitate sympathy strikes, blockades and picketing. I then assume that unions are more concerned about the welfare of insiders than of outsiders.

Moreover, regardless of whether or not job-security legislation increases equilibrium unemployment, there is no doubt that it increases unemployment persistence, i.e., movements either away from or toward the equilibrium unemployment rate will decelerate. More specifically, this type of legislation tends to stabilize (un)employment at the level that happens to exist. If the economy is initially close to full employment, unemployment tends to be stabilized at a low level; this was the situation in most West European countries in the period 1955-1975. The welfare implications are grimmer if unemployment is high initially, for instance, as a result of a recent negative macroeconomic shock, such as in the period 1975-1995. In this case unemployment is stabilized at a high level. Indeed, I have argued elsewhere that the prolonged period of high unemployment in Western Europe during the 1980s and 1990s had more to do with high unemployment persistence than with an asserted increase in the equilibrium unemployment rate (Lindbeck, 2001).

Such unemployment persistence may be the result of behavioral adjustments of either insiders or outsiders, or both. One example is that after a recession, insiders may use their market powers to push up wages in a subsequent business upswing without much concern for the employment prospects of outsiders, thereby reducing the willingness of firms to hire workers. It is also well known that outsiders' possibilities of returning to work tend to fall by the length of their unemployment spells. Losses in skills and self-confidence also reduce the 
re-employment of outsiders. These are some reasons why both job-security legislation and long-lasting unemployment benefits tend to increase unemployment persistence. It is often hypothesized that low investment in real capital during prolonged periods of recession results in sluggish demand for labor in the aftermath, which may also reduce the demand for labor and contribute to unemployment persistence.

Unemployment persistence may be further accentuated by endogenous changes in the work ethic and social norms in conjunction with long periods of mass unemployment. In a short- and medium-term perspective, ethics and social norms in favor of work, and against living on benefits, are likely to constrain the disincentive effects on work of labor-income taxes and subsidies of non-work. But this inertia is likely to recede if a large fraction of the population is unemployed for long periods of time, assuming that social norms are upheld by the approval or disapproval of employed workers. Thus, the greater the number of individuals who live on benefits, the more socially accepted we would expect this way of life to become (Lindbeck, 1995; Lindbeck, Nyberg and Weibull, 1999). Here, then, is another potentially important mechanism behind unemployment persistence. It is reflected in common talk about "unemployment cultures", although we know little about the quantitative importance of this asserted phenomenon.

Needless to say, some welfare-state arrangements may instead reduce structural unemployment. The most obvious example is the school system. An upgrading of general skills among low-skilled workers presumably helps them to get jobs - at least when there are effective wage floors due to high minimum wages or high reservation wages due to generous transfers to individuals out of work. Thus, the existence of wage floors, which in themselves may contribute to unemployment among unskilled workers (if the floor is high enough), strengthens the case for policy actions to improve the education and training of low-skilled workers.

Reduced payroll taxes for low-skilled workers, or outright "in-work benefits", comprise another strategy to boost their employment prospects in the case of rigid money wages. But since such subsidies are reduced when an individual acquires more skill, they necessarily imply increased implicit marginal taxes on investment in human capital. This, of course, may be counteracted by higher education subsidies. In this sense, employment subsidies and education subsidies are complements rather than substitutes.

\footnotetext{
${ }^{5}$ It is true that unemployment has tapered off cyclically during boom periods in Western Europe in the mid1990 s and early 2000s, but only to about 8 percent (open unemployment). This figure, of course, is vastly higher than those typical of boom periods during the 1960s and 1970s. It is difficult to know exactly how institutional conditions should be altered so as to contribute to reduced unemployment. While some unemployment-reducing reforms were brought about via confrontation with labor unions during the Thatcher era in the UK, reforms and adjustments with favorable employment effects turned out to be feasible in the Netherlands via agreements among unions, employers and the government.
} 
So-called active labor-market policy might also be expected to mitigate structural unemployment through better matching between jobs and workers, which is likely to reduce both the equilibrium unemployment rate and unemployment persistence. A large number of studies, however, indicate that the quantitative effects of such policies are quite limited (Calmfors, Manning and Saint-Paul, 1998; and Katz, Stanley and Kruger, 1998).

One specific problem with so-called "active" labor-market policy is that it facilitates the manipulation of unemployment statistics. By simply putting a book in the hands of all unemployed workers, and calling them students or trainees, "open" unemployment could in principle be reduced to zero without any increase in regular employment. Moreover, not only workers with early retirement but frequently also "discouraged" workers are often removed from labor-force statistics. This means that the employment situation in a country is often better described by the fraction of individuals of working age who are employed "employment rates" for short - than the unemployment rate. While these rates were about the same, approximately 65 percent, in most OECD countries in the early 1960s, the figures have recently diverged considerably. In the United States and the Nordic countries, the rates had reached the interval 70-77 percent by the end of the 1990s (after having been above 80 percent in Finland and Sweden in the late 1980s), while the EU average had fallen to about 60 percent.

The division of workers into insiders with good and stable jobs and outsiders with recurrent periods of (often prolonged) unemployment, or work in the informal sector, also has wide repercussions beyond the labor market. Since outsiders have smaller economic resources than insiders, they are often forced to abstain from social activities enjoyed by others, which weakens their social networks. Moreover, many important welfare-state entitlements and subsidized services are tied to current or previous work, which contributes to excluding outsiders from such welfare-state arrangements. In particular, youngsters without a foothold in the labor market often have to rely on quite ungenerous, often means- tested social assistance - when they do not live on handouts from their parents. Here then is a clear example of a conflict between incentives and distributional aspects. On the other hand, when expected future benefits are (positively) tied to work, such benefits have positive incentive effects on work, which counteracts various work disincentives of taxes and means-tested benefits.

\footnotetext{
${ }^{6}$ It could be that these studies underestimate the long-term positive employment effects of such policies. More specifically, it is conceivable that unemployed workers involved in active labor-market programs, such as training and public works, do not lose their skills and work habits as fast as openly unemployed workers. If so, active labor-market policy may make the supply of skilled labor more elastic in subsequent booms, thereby contributing to lower structural unemployment in later upswings. So far, there is not much systematic empirical information about such conceivable long-term effects.
} 
Social exclusion may also be intensified by conditions in the housing market. There is always a general tendency toward segregation in the housing market based on income and profession. A specific type of segregation may arise in urban housing markets with rent control and a related housing shortage (excess demand for apartments). There will be a division between housing-market insiders, with direct apartment contracts, and housingmarket outsiders without such contracts. In this situation, apartments will mainly be acquired via personal networks and black-market transactions. Low-income groups, including many young people and immigrants, are particularly hard hit in this respect. A positive correlation would also be expected between being an outsider in the labor market and the housing market.

The punch line of this discussion is that the welfare state has a long way to go in order to adjust to changing tides in the structure of the labor market.

\section{Changes in the Family}

\subsection{Household types and life cycle}

The ambitions of the traditional welfare state to protect male-breadwinner families against income losses explain its emphasis on full employment, unemployment insurance, sick-leave insurance and pensions for the breadwinner and his survivors in case of death. Recent changes in household structure, life cycle, and values make this type of welfare state less relevant than it used to be. In particular, male-breadwinner households now constitute less than a third of families in most developed countries (Mclanahan, Casper and Sorensen, 1995, Table 11.3). Two-earner households constitute (on average) about 40 percent of households in the Nordic countries and about 25 percent in Southern Europe (Italy and Spain), with other countries in Western Europe in-between, usually about 30 percent (Luxembourg Income Statistics). Single-parent households now average 14 percent of households in EU countries, ranging from 8 percent in Greece and Spain to 23 percent in the UK (Eurostat, 1998b).

Growing numbers of two-earner and single-parent households have heightened the political pressure for subsidized child care outside the household. Up to a point, subsidies to child care and old-age care outside the household can also be justified on efficiency grounds, since they counteract tax distortion in favor of household work. In the case of small families, for example, this tax distortion discourages the exploitation of returns to scale in child care and old-age care. The issue becomes more complex, however, if we add political complications. For instance, it has been observed in many countries that politicians often tend to combine such subsidies with highly arbitrary rules and costly regulations regarding the 
conduct of such care, i.e., in terms of the physical premises, including space and construction, administration - and, in the case of child care, also types of toys, curriculum, etc. Moreover, in some Nordic countries, for instance Sweden, child-care subsidies outside the family are now higher than required to compensate for the tax distortion, at least for families with more than one child. This, of course, means that the government-imposed distortion changes sign in the case of such families.

As regards families with little education or severe problems (including criminality and alcohol or drug abuse), subsidized child care outside the household may also promote investment in human capital. Indeed, there is empirical support for this view (Leibowitz, 1996, Heckman 1999). There may also be an externality argument for subsidies to child care outside the family in such cases, for the purpose of mitigating social misbehavior later on in life.

Whereas two-earner households rarely exhibit poverty, it is well documented that households with a single adult, in particular with children, are highly exposed to economic distress, and even poverty. For instance, child poverty in one-earner households is often three or four times as frequent as the corresponding rates in two-earner households (Mclanahan, Casper and Sorensen, 1995; Bradbury and Jäntti, 2001). A basic reason is that labor-force participation among single adults with children is low in most countries. Another reason is that returns to scale in household service production cannot be exploited in such households. Moreover, there are no adult household members with whom income risk can be pooled. Indeed, besides long-term unemployment, single parenthood seems to be the most important socioeconomic factor behind poverty, including child poverty (Esping-Andersen, 1999, pp.161-163).

Although explanations of the rise in single parenthood are manifold, including increased labor-force participation of females, it is obvious that various welfare-state arrangements also have an impact. There is a strong ethical case for government support to

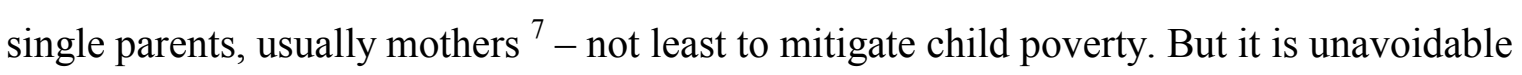
that women then find it financially easier to become single mothers, through childbearing as well as divorce - another example of moral hazard in welfare-state policies. It is also likely that social norms against being a single mother have diminished in recent decades. There is probably mutual causation in this case: while weaker norms against being a single mother result in more of them, more single mothers are likely to weaken the norms.

The generosity of welfare-state support to single motherhood differs considerably among countries. In the United Kingdom, the United States and some countries on the European continent such support is usually modest, and mainly confined to transfer 
payments. In the Nordic countries, not only are transfers more generous; they are also combined with priority for single mothers to receive strongly subsidized child care outside the household. The latter, of course, helps explain the high labor-force participation of single mothers in these countries. For instance, more than 80 percent of single mothers in Sweden worked in the early 1990s, while the EU average was 68 percent and the figure for Great Britain only about 50 percent. The situation in the United States is not much different, about 45 percent (Gornick, 1994). The question of how problems related to single motherhood should be dealt with politically is a complex and controversial issue. The policy trend, however, is to require them to work or acquire education and training, which often presupposes subsidized child care.

Another aspect of the increased heterogeneity of households is based on tendencies to choose a less "linear" life cycle between education, work and non-work than earlier. Specifically, individuals tend increasingly to shift back and forth between periods of work, studies, sabbatical, work abroad, etc. One explanation may be that higher incomes in society result in increased diversity of individual "life projects", similar to the way rising income diversities product demand. But it is also likely that preferences and attitudes are gradually undergoing change in the sense that individuals with given income want to realize idiosyncratic life projects; for evidence of such changes in values, see Inglehart and Baker (2000). This "individualization" of preferences may be a result of higher education and/or demonstration effects from other countries. It is clear that traditional welfare-state arrangements, based on the assumption of a linear life cycle, are too inflexible to satisfy the needs and desires of individuals today to finance periods of non-work for reasons other than bad health, unemployment or old age.

Moreover, pensions are often tied to income earned late in working life, such as in the last ten or fifteen years of work. In a society with idiosyncratic fluctuations in income over the life cycle, sometimes with particularly high income early in life, such arrangements are not appropriate. From this point of view, there is now a stronger case for tying pensions to lifetime income, or lifetime contributions, rather than to income late in working life.

Increased family instability in many countries after World War II has also created intra-family distributional problems for social-insurance entitlements. The traditional system was largely designed to protect widows and their children. But since females increasingly have their own income from work, the need for special social-insurance benefits for widows has declined. Here, a delicate normative issue is how fast pension rights for widows should be phased out. (In Sweden, out-phasing has been so rapid that many widows - a group with little political clout - have become severely disadvantaged.) Instead, there is a growing social

\footnotetext{
${ }^{7}$ Women account for 84 percent of single parents in Western Europe (Eurostat, 1998b).
} 
problem for divorcees when one partner (usually the woman) has lost momentum in her labor-market career because of childbirth, and has not yet accumulated enough pension claims. In some cases, this is bound to create economic hardship in old age for at least one partner. An obvious solution in the event of separation is to split pension claims between spouses - perhaps also between other types of long-term cohabitants. Here, then, is another example where contemporary welfare-state arrangements are not well adjusted to today's social conditions.

Recent socioeconomic changes also have important implications for housing policy. Greater instability of family structure - due to divorce, remarriage, changes in cohabitation patterns and ambitions among the young to set up housekeeping on their own - has made rent control, with a resulting "housing shortage" (excess demand for housing), a more severe social problem than in the past. Unstable families require a flexible housing market, which presupposes equilibrating rents ("market rents") with a reserve (a few percent) of empty apartments at every point in time.

\subsection{Individual responsibility}

In addition to new socioeconomic developments and changing values among voters, new views and values among politicians also explain current approaches to welfare-state reforms. One important example involves encouraging greater individual and family responsibility - a parallel to the increased responsibility recently given to individual workers in reorganized firms. This tendency may be seen as a reaction against the paternalistic notion that the government, in popular jargon, should take care of an individual from "cradle to grave".

The new emphasis on "workfare" rather than "welfare", not just for single mothers, is one such attempt to boost individual responsibility. More generally, politicians and policy advisors seem to be increasingly sympathetic toward shifting away from policies that subsidize non-work. There is a tendency either to take a neutral stance regarding the choice between work and non-work or, more frequently, to adopt policies that actively promote work (as in the case of employment subsidies or tax credits for low-wage groups).

Even leaders of traditional leftwing parties, such as the UK Labor Party, have recently emphasized the individual's responsibility for his own economic situation. Some leaders of the Democratic Party in the US, including the Clinton Administration, have expressed the same view; indeed, this vision is behind the 1997 social assistance reform in the United States - designed to abolish “welfare as we know it” in President Clinton's words. Although 
macroeconomic efficiency would clearly be improved by such a shift, the consequences for the financial position of the government are less clear.

Another important example of reforms designed to enhance individual responsibility concerns proposals for shifting to pension systems with individual accounts. This may be achieved either by establishing a tight link between contributions and benefits in the context of pay-go systems with "notional" accounts - a so-called "notional defined-contribution" system - or by shifting to fully funded, actuarially fair systems. If there are only weak links (or no links at all) between contributions and benefits in an existing pay-go pension system, such shifts also imply less distortion of work and hence higher economic efficiency.

The emergence of broad and highly liquid international capital markets, and the development of new types of capital-market instruments which provide more options regarding the degree of risk exposure, have strengthened the case for fully funded pension systems with individual accounts. However, a shift to a fully funded system also has interand intragenerational redistributional consequences. For instance, if one or a few early ("transition") generations are forced to honor the pension claims of existing pay-go pensioners, subsequent generations will be favored at the expense of earlier generations. Subsequent generations will enjoy a return on their mandatory saving equal to the market interest rate, which is usually higher than the return in pay-go systems (which tend to equal the growth rate of aggregate labor income). Under this scheme for honoring the claims of existing pay-go pensioners, a shift to a fully funded system would tend to increase aggregate national saving for a while, which is also to the advantage of future generations. Indeed, this is often regarded as a main rationale for such a shift (Feldstein, 1995; Kotlikoff, 1998). This rationale, of course, is basically an issue of redistribution of income - from current to future generations.

It is also unavoidable that shifts to fully funded systems, with individual choice of fund managers, widens the dispersion of pensions within generations, since some managers will be more successful than others. This merely illustrates the general principle that greater individual freedom of choice tends to create increased differences in outcome.

The case is stronger for a partial rather than a total shift to a fully funded pension system, since better diversification of the "portfolio" of pension claims is achieved in the former system. Not only does the market risk differ between pay-go and funded pension systems - risk regarding the development of the tax base in the first system and capitalmarket risk in the second. The political risks also differ, and are probably as a rule greater in

\footnotetext{
${ }^{8}$ The effects depend partly on the elasticity of labor demand with respect to real wage costs. While some authors, such as Sinn (2000), have argued that the financial position of the government will improve, others such as Burtless (1994), assert that the opposite is likely to be the case.
} 
the case of pay-go systems, since property rights are likely to be stronger in fully funded systems with individual accounts. Anyway, by combining the two systems, it would be possible to pool various types of market risks and political risks, and hence achieve a reduction in total risk.

One serious problem with mandatory fully funded pension systems is that it may be difficult to prevent future politicians from intervening in the portfolio management of pension funds created by the government, and from exercising voting powers in firms in which the funds hold shares. It would be tempting for future politicians to ague: "why should taxpayers in our country finance investments in other countries, when many of our own industries and regions need more investment?" And: "why is it that politicians, representatives of the people, should not appoint board members of firms in which the voters' pension contributions have been invested?" In other words, capital cannot be nationalized - whether in governmentrun pension funds or otherwise - without risking politicization of the national economy. It is not necessarily helpful to instill a regulation according to which mandatory pension funds should invest in mutual funds or foreign stocks. Future politicians with ambitions of power can always change such regulations. The most promising way of minimizing the risk of politicization is probably to let each citizen choose among a number of competing private funds from the very beginning. This is likely to impede future politicization since outright nationalization of private pension funds would then be necessary.

Of course, the administrative costs for competing pension funds are likely to be higher than for a unitary government operated fund, at least in countries with a reasonably wellfunctioning government administration. But adherents of a pluralistic society may be willing to pay a price, not only in terms of greater dispersion of the distribution of pensions but also in the form of higher administrative costs, in order to enhance the survival of a pluralistic society. Administrative arrangements could also be implemented to curtail these costs, for instance, by lids on the fees in mandatory pension funds, which would prompt many fund managers choose index-type funds.

A more radical proposal, also designed to confer on the individual more responsibility for his own income security, would be to replace the many different types of welfare-state arrangements currently in effect with a unified system of compulsory saving with individual accounts and "drawing rights" (Fölster, 1999; Orzag and Snower, 1999). The characteristic feature of such a system is that an individual would be allowed to draw on his account before retirement for certain specified purposes, such as education, sabbatical, sick leave and unemployment. What remains in the account at the time of retirement would determine the size of his pension. Thus, an individual would have greater freedom than today to reallocate welfare-state entitlements over his life cycle according to idiosyncratic preferences. This 
reform also fits nicely with individuals' desire to choose a less linear life cycle than in the past. For the time being, the most obvious real-world example of such a system is the central provident fund in Singapore.

\subsection{Production and provision of welfare-state services}

While contemporary changes in family structure increase the demand for child care and old-age care, higher real income and increased longevity tend to raise the demand for education and health care, probably also as a share of GDP. The mechanism of Baumol's (1967) law, based on a relatively slow increase in productivity for many personal ("human") services, also tends to raise aggregate spending on personal services as a share of GDP. In addition, medical advances will most likely contribute to higher aggregate health-care spending as a share of GDP, for instance due to new surgical procedures for "repairing" the human body. In all of these cases, welfare-state policies, of course, boost these demands via subsidies or mandatory insurance.

These developments accentuate the problem of deciding who should provide and produce the services in exertion. In several countries in Western Europe, again notably the Nordic nations, the public sector is in charge of both the provision and the production of these services. This has been brought about by a combination of regulations and subsidies mainly confined to the public sector. In fact, personal (human) services - education, health, child care and old-age care - have largely been socialized in these countries. This is reflected in employment statistics. While the public-service sector accounts for about 25 percent of total employment in the Nordic countries, the average for Western Europe is about 18 percent (OECD, 1998). In the United States, where taxes are relatively low and the dispersion of wages relatively wide, market purchases of such services (including arrangements provided by employers) are instead relatively large. As a result, while the number of individuals (officially) engaged in personal services in the private sector is only 5-6 percent of the labor force in Western Europe, it is about twice as large in the United States (Elfring, 1988, Table V.3).

At the same time as several personal ("human") services have shifted to the government sector, the production of a number of "material services" has shifted from the market to the household (Lindbeck, 1988). The reason is that the tax system favors home production of services in general - including repairs, cleaning and gardening. I suppose Karl Marx would have been surprised by this combination of socialized household production of personal (human) services and a shift of various material services from the market to the household - while manufacturing production has remained in the private sector. 
It is not obvious why governments in some countries have thus created near-publicsector monopolies for both provision and production of important personal services. One conceivable explanation is that such policies tend to change the distribution of income to the disadvantage of high-income families that choose to buy non-subsidized private services, at the same time as they have to pay taxes to finance services for others. They then have to "pay twice" (Besley and Coate, 1991; Blomquist and Christiansen, 1995). Another explanation may be that public-sector service monopolies make it easier for politicians and public-sector administrators to control the type, quality and distribution of such services. But why would a majority of voters support such arrangements, which largely do away with individual freedom of choice in these areas? Today, it may well be that only a small minority of voters are concerned about freedom of choice for services such as child care and old-age care, in particular if most families are basically content with the quality of government-produced services. The absence of freedom of choice may be a serious concern only for those who adhere strongly to the principle that individuals should be free to choose.

However, as time goes by, higher income and better education are likely to increase households' interest in obtaining more individually adjusted services and hence more individual freedom of choice in the future. Again, this would be a parallel to the observed high income elasticity of demand for product variability in the case of private goods and services. As a result, welfare states that favor public-sector service monopolies are likely to be less and less in touch with the values of a large number of their citizens.

One increasingly popular way of creating competition in the production of such services is different forms of outsourcing, sometimes after competitive bidding among private services producers. While this procedure may increase efficiency and innovation in production, it hardly increases the freedom of choice among consumers. As we know by now, it is not administratively difficult to combine freedom of choice with subsidies to "social services". Service checks (vouchers) allow households to buy services wherever they like, or to cash the checks and produce the services themselves. It is not obvious why the case for freedom of choice, competition and innovation (experimentation) should be weaker in these areas than in the case of ordinary consumer goods. Administratively, voucher systems are much easier in the case of child care and education than in the case of old-age care, since the service needs of the elderly vary enormously depending on the individual's health situation.

The most common argument against vouchers seems to be that they might increase institutional segregation along the lines of income, education and profession. But this argument is far from obvious. There is considerable housing segregation in most countries, which means that service vouchers give low-income families living in geographical areas with poor service institutions a chance to acquire services from better institutions in other 
geographical areas - today a privilege mainly confined to the rich. Vouchers may then, in fact, contribute to institutional desegregation of child care, education and old-age care services.

In the case of education, a specific argument against vouchers is that public-sector schools may lose some of their best students and most able teachers, and that this will lower the quality of education for the remaining pupils in such schools (Hirschman, 1970; Epple and Romano, 1998). But there is also an opposite hypothesis, namely that increased competition stimulates the performance of all schools, including those in the public sector and that, as a result education becomes better adjusted to children's different needs and parents' different wishes also in public-sector schools (Hoxby, 1994). The empirical studies carried out so far do not lend support to the negative hypothesis; there is rather some support

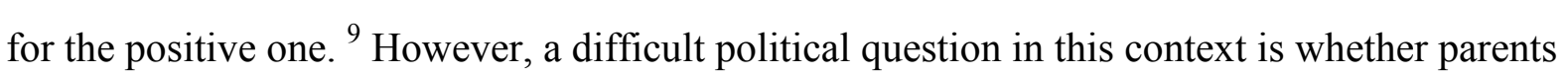
should be allowed to add cash payments to vouchers to obtain more expensive education for their children. Individuals subscribing to the view that certain types of personal services should be more equally distributed than purchasing power in general are likely to argue in favor of restrictions on allowing parents to add private cash to vouchers.

Contemporary changes in information and communication technology (ICT) are likely to have important consequences for public-service production. Trivially, ICT reduces the individual's costs of acquiring information about public-sector activities, including rules concerning social insurance and welfare-state services. ICT also makes it cheaper to administrate individually adjusted, and hence more differentiated, social-insurance systems, including both pension systems with individual accounts and compulsory saving with individual drawing rights.

The Web also enables individuals to learn from the experiences of others regarding specific public-sector services, evaluated from the consumer's point of view. Moreover, as new fora gradually emerge on the Internet, individual citizens can express their opinions not only about goods in the private sector, but also about specific public-sector services - such as child care, education, health care and old-age care at specific institutions. An individual will then be able to air his views not only on the Website of politicians and public-sector institutions, but also on non-government sites: virtual communities, news groups and chat groups managed by independent agents. When many individuals openly express their views in cyberspace, politicians and public-sector administrators will find it difficult to neglect complaints and suggestions (Lindbeck and Wikström, 2000).

In other words, the Internet is likely to enhance the individual's voice option, in Hirshman's (1960) terminology, regarding public-sector services. This is important in the 
sense that voting is a very inefficient way of voicing opinions about specific public-sector services, such as a particular school or child-care institution. After all, general elections only enable an individual to comment on broad "packages" of policy measures proposed by political parties or individual candidates.

A voice option via the Internet would be even more powerful if it were accompanied by an expanded exit option, which is exactly what vouchers would bring about.

Correspondingly, exit options are more valuable if the individual is well informed, for instance via the Web. Thus, voice options by way of the Web and exit opportunities by way of voucher systems are highly complementary mechanisms.

\subsection{Family orientation vs. individual orientation}

The developments discussed above - concerning family structure, life cycle and values - challenge both the family-oriented, transfer-heavy welfare states on the European continent and the more individually oriented, public-service-heavy welfare states in the Nordic countries. The former type of welfare state emphasizes family stability and familyprovided services to family members, while female labor-market participation is discouraged. ${ }^{10}$ The fact that birth rates today are not higher in these countries than in countries where more women work outside the home suggests that low labor-force participation among females is no guarantee for high fertility.

Generally speaking, the Nordic welfare states are more individual oriented in the sense that taxes and benefits are tied to individuals rather than to families, and that welfarestate arrangements are adapted to women's ambitions to participate in the labor market. In particular, the availability of subsidized child care and old-age care outside the family is likely to mitigate the conflict between female labor-market participation and personal services for household members. One obvious "cost" is high tax rates and, in reality (though not by necessity), strongly restricted freedom of households to choose a service provider since public-sector provision and production of personal services is emphasized. In practice, these countries also exhibit strong gender segregation in the labor market - a concentration of women in the public sector and men in the private sector. For instance, in Sweden, 51 percent of the female labor force work in the public sector, and 73 percent of the employees in this sector are females (Statistics Sweden).

Some advocates of Nordic-type welfare states regard generous transfers to households as instruments for making individuals less dependent on the labor market - a "de-commoda-

\footnotetext{
${ }^{9}$ For a survey of the literature, see Bergström and Sandström (2001), who also present a study for Sweden.

${ }^{10}$ Child care by parents and other relatives is important in all countries. Esping-Andersen (1999, p. 64) reports that such child care accounts for about 30 percent of total child care in Denmark, 50 percent in the US and 83 percent in Britain - and probably the lion's share also in Germany, Italy and Spain.
} 
tion" of individuals in Marxian jargon (a concept elaborated by Polanyi, 1944). But somewhat paradoxically, it is precisely in this type of welfare state that married (and cohabiting) women are actually "commodized", since their high labor-force participation makes them directly dependent on the labor market (Esping-Andersen, 1999). Moreover, a common assessment is that families with two adult labor-market participants often find that time is extremely scarce, a point made forcefully long ago by Burenstam Linder (1970). Married females have adjusted to this dilemma not only by working part-time but also by cutting the number of hours of work in the home as compared to housewives (EspingAndersen, 1999, p. 629).

The question of what would be an appropriate strategy for welfare-state reforms from a normative point of view depends, of course, on what type of society we strive to realize. Moreover, women's ambitions to participate in the labor market can be satisfied in different ways. One way is through a US-type strategy of high flexibility (and wide dispersion) of relative wages, possibly combined with negative income taxes associated with work (such as "work-in-benefits" or tax credit to individuals with small earnings). Another way is the Nordic strategy of generous subsidies to child care and old-age care outside the household. In turns out that total social spending (public-sector plus private) ${ }_{\text {does not differ dramatically }}$ between these two types of countries even though the proportions between government and private financing and provision differ considerably (Forsell, Medelberg and Ståhlberg, 2000; Esping-Andersen, 1999, pp.175-178).

\section{Macroeconomic Developments: Instability, Growth and Internationalization}

\subsection{Short-term macroeconomic instability}

Recent experiences of short-term macroeconomic fluctuations in developed countries provide interesting lessons for the welfare state. The traditional Keynesian view, of course, was that generous welfare-state arrangements help reduce cyclical fluctuations in aggregate output and employment since disposable income is held stable by the "automatic fiscal stabilizer". This theory is still relevant in the case of modest business cycles. But as we know, this view has recently been challenged. I then refer not to the "Ricardian equivalence" hypothesis, according to which the effects on aggregate demand (abstracting from disincentive effects via tax distortions) are independent of the way in which government spending is financed (by taxes or borrowing). Nor do I refer to views developed by a number of German economists in the 1980s to the effect that higher government spending may create

\footnotetext{
${ }^{11}$ I include in this concept child care, education, health care and old-age care outside the family.
} 
expectations about permanently higher taxes in the future, which are assumed to reduce private spending and hence have negative macroeconomic effects (see the discussion in Giavazzi and Pagano, 1990. 12

Instead I consider recent experience in Finland and Sweden, which suggests that the automatic fiscal stabilizer may turn into an automatic de-stabilizer in the case of huge negative macroeconomic shocks if these undermine confidence in the ability of the government to live up to its financial commitments. There are at least two reasons for such a destabilizing effect due to increased uncertainty about government behavior. If the budget deficit and, as a consequence, public-sector debt explodes, lenders may lose confidence in the government's ability to service the galloping debt. They then require higher - possibly much higher - interest rates, with restrictive macroeconomic effects as a result. The crowding out of private spending may then be much larger than that predicted by traditional static Keynesian (IS-LM) models (where the crowding-out effect can never be larger than the initial stimulation of aggregate demand via a higher budget deficit).

Another reason why galloping government debt during a recession may have restrictive rather than expansionary macroeconomic effects on the national economy is that households may lose confidence in the government's ability to grant promised welfare-state entitlements. A predicted effect of such an increase in uncertainty is a rise in the financial saving rate of households, in particular via reduced purchases of durable consumer goods. This also tends to deepen a recession. 14.

All this means that the harmony which used to be assumed between the welfare state and macroeconomic stability, in the Keynes-Beveridge tradition, has been shattered to some extent (Lindbeck, 1997a). In particular, this may happen in countries where the budget balance is very sensitive to changes in macroeconomic activity, which is the case in countries with highly ambitious welfare-state arrangements.

\subsection{Economic growth}

While rapid economic growth during the first post-World War II decades facilitated the financing of welfare-state spending, it is a commonplace that the growth slowdown from the mid-1970s contributed to the emerging financial problems of the welfare state. At the same time as the tax base became more sluggish, various welfare-state entitlements, often

\footnotetext{
12 These studies have looked mainly at the possibility that lower government spending has expansionary macroeconomic effects.

${ }^{13}$ In the early 1990s, real interest rates on private loans in Finland and Sweden increased to 10-15 percent.

${ }^{14}$ For instance, in the early 1990s, the household saving rate in Sweden increased from minus 3 to plus 9 percent, which corresponded to a fall in domestic aggregate demand by about 7 percent. The difficulties in stimulating household consumption via budget deficits in Japan in the 1990s may be a similar phenomenon.
} 
based on earlier macroeconomic developments, continued to expand. This helps explain the emergence of budget deficits in several countries.

But what about the possibility of reverse causation - from the welfare state to longterm economic growth? The most obvious example of positive growth effects, at least during a period of transition, is probably government subsidies to investment in human capital education, training programs and to some extent also health care (though perhaps not in the case of retired individuals). It is also generally believed that income protection contributes to social tranquility, and that this in turn promotes economic efficiency and growth by preventing disruptive social conflicts. Indeed, there is some empirical support for this hypothesis (Alesina, Ozler, Roubini and Swagel, 1996).

One widely quoted welfare-state arrangement with negative effects on GDP growth, at least during a period of transition, is the introduction of pay-go social insurance systems. The reason is that the "gift" to the first generations of pay-go pensioners increased their consumption and hence reduced aggregate saving. Moreover, as pointed out, in particular by Martin Feldstein (1995), existing capital-income taxes are likely to have depressed physical capital formation over a number of years. Various asymmetries in such taxes also distort the allocation of investment among sectors and firms, with negative effects on economic growth. Similarly, progressive taxes on earnings are likely to have reduced the incentives to invest in human capital, hence counteracting the positive effects of various educational subsidies on such investment. Most likely, gradually larger marginal tax wedges on labor earnings during the 1960s, 1970s and early 1980s in many countries reduced not only economic efficiency but also economic growth during a period of transition.

I would hypothesize that the negative growth effects will be particularly pronounced if welfare-state egalitarianism spreads to the business sector. An example is attempts by the government to squeeze profits and to tax wealth of small entrepreneurs as part of redistribution policy, since real investment then tends to fall. If the government, as in Sweden during the 1960s and 1970s, responds to such a fall by selective subsidies to ailing firms, the allocation of resources is bound to be distorted, and economic efficiency and (at least during a period of transition) the growth rate to decline. A combination of double taxation of profits,

\footnotetext{
${ }^{15}$ It has also been argued by Hans-Werner Sinn (1996) that increased income security provided by various welfare-state arrangements promotes economic growth, since entrepreneurs are then willing to accept greater risk. This cannot possibly be a decisive point. The big risk for entrepreneurs involves losing their equity capital, and welfare-state arrangement and/or taxes do not compensate for such risks. As a rule, the probable alternatives for an entrepreneur are to start a new firm or accept becoming an employee - rather than living on welfare-state benefits, such as unemployment benefits or social assistance.
} 
high wealth taxes and high inheritance taxes is also likely to harm the entry and expansion of small firms.

The basic issue, however, is not whether the welfare state as a whole boosts or retards economic growth, but rather at what level of welfare-state arrangements, and related financing, the negative effects of additional spending start to dominate the positive effects. This way of looking at the issue is evidently based on the observation that the marginal disincentive effects of explicit and implicit taxes increase with the rates, and the assumption that governments, to begin with, choose growth-enhancing rather than growth-retarding programs. This is the background for the usual hypothesis of a non-linear (concave) relation between welfare-state spending and economic growth, with an internal maximum point for the growth rate. This view of the world, however, is complicated by the fact that the consequences of welfare-state arrangements (and their financing) for economic growth depend crucially on the exact design of these arrangements, including the structure of taxes a point pursued, for instance, by Atkinson (1999a). Indeed, there is not even any guarantee that a government will initially choose taxes with modest rather than huge distortions, and that it will begin the welfare-state buildup by implementing systems with positive rather than negative effects on economic efficiency and growth.

All this means that we cannot hope to find a robust empirical relation between the aggregate level of welfare-state spending, on one hand, and economic efficiency and aggregate economic growth on the other hand. Thus, it is very difficult to ascertain the level of welfare-state spending at which unfavorable effects on efficiency and growth start to dominate the favorable ones.

\subsection{Internationalization}

It is a commonly held view today that the gradual internationalization of the economic system ("globalization") will force countries to scale down their welfare-state ambitions. It is true that the possibilities of taxing capital much more highly in one country than in others have receded considerably, and that this may generate "downward tax competition" in the case of capital taxation. Government revenues from capital taxes, however, usually comprise only a few percent of total government tax revenues. Thus, the main problem with receding

\footnotetext{
${ }^{16}$ Indeed, in Sweden during the 1960s and 1980s, tax rates on capital investment by owners of small firms were often close to, or even higher than, one hundred percent in real terms. I have hypothesized that this "extension" of redistribution policies to the business sector was an important explanation for the slow growth in Sweden relative to other countries during the last quarter of the 20th century (Lindbeck, 1997b).This policy was gradually abandoned in the late 1980s and early 1990s.

${ }^{17}$ Overall, in the case of rich countries, ambitious econometric studies tend to find a negative relation between the share of aggregate government spending (or taxes) and economic growth; see, for instance, Fölster and Henrekson (2000). Even if this result makes sense to many observers, including myself, we cannot feel confident about the quantitative aspects.
} 
national autonomy in capital taxation is not really that it becomes more difficult to finance the welfare state. Nevertheless, there will certainly be an increased conflict between attempts to reduce disposable income of the very rich (for whom income from capital is important) and ambitions to keep up domestic capital formation. Presumably this conflict is particularly strong in the case of owners of small and medium-sized firms because they require family capital and other types of domestic equity capital.

Moreover, to the extent that the internationalization of product and labor markets is responsible for the recent widening of the distribution of earnings in some countries, it becomes more difficult to squeeze the distribution of earnings. A long time ago, Gunnar Myrdal (1968) pointed out that countries with generous welfare-state arrangements and strongly egalitarian ambitions will undergo strong pressure for immigration of low-skilled workers. He predicted that this will induce such countries to pursue quite restrictive immigration policies for low-skilled workers. Moreover, to mitigate tendencies toward downward benefit competition, some authors, such as Sinn (2000), have suggested that benefits for immigrants should be tied to the benefit levels in their home countries, rather than their host country.

So much for capital and (low-skilled) labor. It is more difficult to judge whether national autonomy has dwindled much, or is likely to do so in the future, in the case of taxation of human capital. Several factors have certainly increased the mobility of human capital: internationalization of firms (including increased role of multinational firms), improved knowledge of foreign languages among younger generations and better information about conditions in other countries. Thus, the risk that countries with high and strongly progressive taxes will face a brain drain has certainly increased, though from quite low levels. While countries have some control of immigration of low-skilled workers through quantitative regulations, attempts to counteract emigration of high-skilled individuals have to rely on other methods, including economic incentives. An individual's choice of country of residence, however, does not depend mainly on marginal tax rates, but rather on his total tax burden relative to total benefits received. It is mainly this relation governments should consider when worrying about brain drain in connection with welfare-state policies. So far, however, the quantitative importance of this type of brain-drain problem has not been overwhelming for rich countries, except possibly for some English-speaking countries. The situation may well change in the future. But it is still too early to say whether much coordination and centralization of welfare-state and tax arrangements will be necessary later on in order to limit brain drain and downward tax competition in the case of human capital.

There is, no doubt, a case for making social-insurance entitlements internationally transferable - a parallel to attempts to make occupation pensions transferable among 
production sectors in the domestic economy. One way of bringing this about is to base entitlements on individual accounts that the individual can take with him when shifting his domicile from one country to another - a method reminiscent of Sinn's (2000) suggestion to tie benefits for migrants to the benefit level in their home countries. While such accounts are typical for fully funded benefit systems, as well as for forced saving with "drawing rights" of individuals, notional accounts in the context of pay-go systems may also be made internationally transferable.

One reason to be somewhat skeptical about assertions that the internationalization process will force countries to make drastic reductions in welfare-state spending is that the most internationalized countries in the OECD area - a number of "small open" West European countries - traditionally have had particularly generous welfare-state arrangements without pronounced brain-drain problems. ${ }^{18}$ As mentioned before, the problem for these countries is rather to limit immigration of low-skilled workers.

There is, however, another way of looking at the increased obstacles to national governments' keeping domestic taxes high on human and financial capital in an ever more internationalized economy. Rather than looking at this as a problem for governments, increased international mobility of human and financial capital may be seen as protection of minorities against threats of being "robbed" by the government or by a majority of voters. The ability of the individual to "vote with his feet" may be regarded as a complement to his right to vote at the ballet box. The exit option is strengthened.

\section{Concluding Remarks}

How, then, have different countries responded to "changing tides" for the welfare state? In most countries, not much has yet been done to adjust the welfare state to new income risks and new service needs. Although attempts have been made in several countries to raise the average pension age, this has turned out to be a politically difficult task. Only a few OECD countries - including Italy, Sweden and Germany - have started major reforms of their pension systems through shifts to "notional defined-contribution" pension systems or partial shifts to fully funded systems.

Adjustment to changes in family structure has also been quite modest in most OECD countries. The most far-reaching change has taken place in the Nordic countries, reflected in legislated paid leave for the care of small children and subsidies to child care outside the family. This is an important explanation as to why labor-force participation in these countries

\footnotetext{
${ }^{18}$ A celebrated explanation as to why these countries have built up quite ambitious programs of income protection is that highly open economies are particularly exposed to the risk of income disturbances emanating from worldwide developments; see Cameron (1978) and Rodrik (1998).
} 
is as high as in the United States, where it is kept up by wide wage dispersion and relatively low taxes. In one important respect, however, the Nordic countries have moved closer to the welfare-state regimes on the European continent: benefits have recently been tied more closely to contributions paid earlier (the "Bismark tradition"), rather than constituting “citizens' rights" independent of contributions. In the UK there has instead been a pronounced shift from universal to means-tested benefits (Atkinson, 1999a).

Reforms of the labor market in response to shifts in supply and demand for labor have also been modest. For instance, not much has been done to improve wage flexibility to accommodate shifts in the composition of the labor force and to mitigate tendencies toward unemployment persistence. The insider-outsider divide in the labor market and society at large also prevails; the Netherlands perhaps is an exception.

There are only modest tendencies to encourage greater freedom of choice concerning types of personal services, for instance via service vouchers, which could potentially strengthen individuals' "exit options". The ICT revolution, which could provide individuals with new tools for a stronger "voice" in the sector of public services, has at most only started to emerge.

The most important adjustment of welfare-state policies during the last two decades is probably that aggregate welfare-state spending - defined as transfers (excluding interest payments) plus public consumption (excluding defense) - has stagnated as a percent of GDP since the mid-1980s in most OECD countries (OECD Economic Outlook, 1999). I then abstract from cyclical fluctuations. One interpretation is that governments have become more aware of the difficulties financing ever higher welfare-state expenditures without severe disincentive effects (tax distortions and moral hazard). In only a very few countries, however, can we observe a clear trend toward lower welfare-state spending during the last two decades - in particular, the Netherlands and Belgium - though several countries (such as Denmark, Finland and Sweden) have cut aggregate welfare-state spending substantially from the cyclical peak levels in the early 1990s.

The overall impression is that it is politically difficult to adjust welfare-state arrangements to new socioeconomic conditions and changing values. One explanation for the difficulties, of course, is that new arrangements have to compete with established programs for which there already exist interest groups, often with strong political influence. In line with Khaneman-Tversky-type theories, it is also natural to assume that voters who lose benefits that they already have will be more perturbed than voters who do not secure new benefits. Hence the risk of losing votes among the former is probably greater than possibilities of gaining votes among the latter. The outcome is either that new arrangements will not develop in response to new demands (the situation in the UK and in most countries on the European 
continent), or that new arrangements are piled on top of the old ones, which during the 1970s and 1980s resulted in very high tax rates in the Nordic countries.

\section{References}

Alesina, A., S. Ozler, N. Roubini and P. Swagel, 1996, "Political Instability and Economic Growth", Journal of Economic Growth, 2, pp. 189-213.

Atkinson, A. B., 1991, "Social Insurance”, Geneva Papers on Risk and Insurance Theory, 16(2), pp. 113-131.

, 1999a, "The Economics of the Welfare State: An Incomplete Debate" in M.

Bruti, D. Franco and L. Pench (eds.), The Welfare State in Europe, Cheltenham, UK:

Edward Elgar.

, 1999b, "Is Rising Inequality Inevitable? A Critique of the Transatlantic

Consensus", Wider Annual Lecture 3, Helsinki: United Nations University.

-------------, 2000, “Income and Earnings Inequality in OECD Countries. Seeking to

Explain Recent Developments", manuscript, SNS and Swedish Trade Union

Conference, Nov. 8, 2000, Stockholm.

Barr, N., 1992, "Economic Theory and the Welfare State: A Survey and Interpretation",

Journal of Economic Literature, 30(2), pp. 741-803.

Baumol, W., 1967, “The Macroeconomics of Unbalanced Growth”, American Economic Review, 57, pp. 415-426.

Becker G., 1981, A Treatise on the Family, Cambridge, MA: Harvard University Press.

Bentolila, S. and G. Bertola, 1990, "Firing Costs and Labour Demand: How Bad is

Eurosclerosis?", Review of Economic Studies, 57, pp. 381-402.

Bergström, F. and M. Sandström, 2001, Konkurrens bildar skola - en ESO-rapport om friskolornas betydelse för de kommunala skolorna (Competition Founds a School -

An ESO Report on the Effects of Private Schools on Local Public Schools), ESO

Report, Stockholm: Treasury Department.

Besley, T. and S. Coate, 1991, "Public Provision of Private Goods and the Redistribution of Income", American Economic Review, 81, pp. 979-984.

Blomquist, S. and V. Christiansen, 1995, "Public Provision of Private Goods as a

Redistributive Device in an Optimum Income Tax Model, Scandinavian Journal of Economics, 97(4), pp. 547-567.

Boeri, T., A. Börsch-Supan and G. Tabellini, 2000, "Would You Like to Shrink the Welfare State?, The Opinions of European Citizens”, manuscript, Bocconi University, Milan. 
Bradbury, B. and M. Jäntti, 2001, "Child Poverty across the Industrialised World: Evidence from the Luxembourg Income Study”, in K. Vleminckx and T. M. Smeeding (eds.) Child Well-Being, Child Poverty and Child Policy in Modern Nations, Bristol: Policy Press.

Burenstam Linder, S., 1970, The Harried Leisure Class, New York: Columbia University Press.

Burtless, G., 1994, "Paychecks or Welfare Checks: Can AFDC Recipients Support Themselves?", Brookings Review, 12(4), pp. 34-37.

Calmfors, L., A. Manning and G. Saint-Paul, 1998, “A Balanced Approach to Employment Policy in Europe", HM Treasury, Working Paper No. 70, London.

Cameron, D., 1978, "The Expansion of the Public Economy: A Comparative Analysis", American Political Science Review, 72, pp. 1243-61.

Edlund, L. and R. Pande, 2001, “Gender Politics: The Political Science of Marriage”, manuscript, March 24, 2001, Columbia University, New York.

Elfring, T., 1988, "Service Employment in Advanced Economies”, Ph.D. dissertation, Department of Economics, University of Groningen.

Epple, D. and Romano, 1998, "Competition between Private and Public Schools, Vouchers and Peer-Group Effects", American Economic Review, 88(1), pp. 33-67.

Esping-Andersen, G., 1999, Social Foundations of Postindustrial Economies, Oxford: Oxford University Press.

European Community, 1994, Social Protection in Europe 1993, Commission of the European Communities, Directorate-General for Employment, Industrial Relations and Social Affairs, Luxembourg: Office for Official Publications of the European Communities.

Eurostat, 1998a, Statistics in Focus, 3-11, Labour Force Survey, Principal Results 1998.

Eurostat, 1998b, Statistics in Focus, Population and Social Conditions, 12, Lone Parent Families: A Growing Phenomenon.

Feldstein, M., 1995, “The Missing Piece in Policy Analysis: Social Security Reform”, American Economic Review, 85, pp. 1-14.

Forsell, Å., M. Medelberg and A.-C. Ståhlberg, 2000, “Olika transfereringssystem men olika inkomster" (Different Transfer Systems but Different Incomes), Ekonomisk Debatt, 28(2), pp. 143-158.

Fölster, S., 1999, "Social Insurance Based on Personal Savings Accounts: A Possible Reform Strategy for Overburdened Welfare States?” in J. Buti, D. Franco and L. Pench (eds.), The Welfare State in Europe, Cheltenham, UK: Edward Elgar.

Fölster, S. and M. Henrekson, 2000, "Growth Effects of Government Expenditure and Taxation in Rich Countries", European Economic Review (forthcoming). 
Giavazzi, F. and M. Pagano, 1990, “Can Severe Fiscal Contractions Be Expansionary? Tales of Two Small European Countries", NBER Macroeconomics Annual 1990, Cambridge, MA: MIT Press, pp. 75-116.

Gornick, J., 1994, “Economic Gender Gaps in Industrialized Countries”, Luxembourg Income Survey, manuscript, Nov.

Gottschalk, P. and T. Smeeding, 2000, "Empirical Evidence on Income Inequality in Industrialized Countries“, in A. B. Atkinson and F. Bourguignon (eds.), Handbook of Income Distribution, vol. 1, pp. 261-307, Amsterdam: Elsevier Science.

Hassler, J., J. Rodriguez More, and J. Zeira, 2001, "Inequality, Mobility and Distribution", mimeo, January 26, 2001, Institute for International Economic Studies, Stockholm.

Heckman, J. J., 1999, “Policies to Foster Human Capital”, paper presented at the Aaron Wildavsky Forum, University of California, Berkeley, June.

Hirschman, A., 1970, Exit, Voice, and Loyalty, Cambridge, MA: Harvard University Press.

Hoxby, C. M. 1994, "Do Private Schools Provide Competition for Public Schools”, NBER, Working Paper no. 4975.

Inglehart, R. and W. Baker, 2000, "Modernization, Cultural Change, and the Persistence of Traditional Values", American Sociological Review, 65(1), pp. 19-51.

Katz, L., M. Stanley, and A. Krueger, 1998, “Impact of Employment and Training Programs: The American Experience”, HM Treasury, Working Paper No. 70, London.

Kotlikoff, L., 1998, "Simulating the Privatization of Social Security in General Equilibrium", in M. Feldstein (ed.), Privatizing Social Security, Chicago: University of Chicago Press.

Leibowitz, A., 1996, "Child Care: Private Costs or Public Responsibility”, in U. Fuchs (ed.), Individual and Social Responsibility, Chicago: University of Chicago Press.

Lindbeck, A., 1985, "Redistribution Policy and the Expansion of the Public Sector", Journal of Public Economics, 28, pp. 39-328.

1988, "Consequences of the Advanced Welfare State", The World Economy, 11, pp. 19-38.

, 1994, "Overshooting, Reform and Retreat of the Welfare State", The Tinbergen Lecture, De Economist, 142(1), 1-19.

, 1995, "Hazardous Welfare-State Dynamics", American Economic Review, Papers and Proceedings, 85, pp. 9-15.

, 1997a, "Full Employment and the Welfare State", Seidman Lecture, The American Economist, 42(1), pp. 3-14.

, 1997b, “The Swedish Experiment", Journal of Economic Literature, XXXV,

pp. 1273-1319. 
-------------, 2001, “Unemployment - Structural”, in N. J. Smelser and P. B. Baltes (eds.), International Encyclopedia of the Social and Behavioral Sciences, Oxford: Pergamon, Elsevier Science (forthcoming).

Lindbeck, A., S. Nyberg, and J. W. Weibull, 1999, "Social Norms and Economic Incentives in the Welfare State" Quarterly Journal of Economics, 114(1), pp. 1-35.

Lindbeck, A. and D. Snower, 1988, “Cooperation, Harassment and Involuntary Unemployment", American Economic Review, 78, pp. 167-188.

---------------, 1996, “Reorganization of Firms and Labor Market Inequality”, American Economic Review, 86, pp. 315-321.

, 2001a, "Centralized Bargaining and Reorganized Work: Are They Compatible?", European Economic Review (forthcoming).

, 2001b, "Insiders versus Outsiders”, Journal of Economic Perspectives, 15(1), pp. 165-188.

Lindbeck, A. and S. Wikstrom, 2000, "The ICT Revolution in Consumer Product Markets", Consumption, Markets and Culture, 4, pp. 1-20.

Luxembourg Income Study, 2001, www.lis.ceps.lu, Madison, WI: Data and Program Library Service, University of Wisconsin-Madison.

Mclanahan, S., L. Casper and A. Sorensen, 1995, Growing Up With a Single Parent, Cambridge, MA: Harvard University Press.

Myrdal, A. and G. Myrdal, 1934, Kris i Befolkningsfrågan (The Population Crisis), Stockholm: Bonniers.

Myrdal, G., 1968, Beyond the Welfare State. Economic Planning and Its International Implications, New Haven, CT: Yale University Press.

Nickell, S. and B. Bell, 1997, "Changes in the Distribution of Wages and Unemployment in OECD Countries", American Economic Review, 87, pp. 302-308.

OECD, 1998, Historical Statistics, 1960-1995, Paris.

OECD, 1999, Employment Outlook, June, Paris.

Olson, M., 1965, The Logic of Collective Action: Public Goods and the Theory of Groups, Cambridge, MA: Harvard University Press.

Orzag, M. and D. Snower, 1999, "Expanding the Welfare System: A Proposal for Reform”, in J. Buti, D. Franco and L. Pench (eds.), The Welfare State in Europe, Cheltenham, UK: Edward Elgar.

Piore, M. J., 1987, "Historical Perspectives and the Interpretation of Unemployment", Journal of Economic Literature, 25, pp. 1834-1850.

Polanyi, K.,1944, The Great Transformation, New York: Rhinehart. 
Rodrik, D., 1998, “Why Do More Open Economies Have Bigger Governments?”, Journal of Political Economy, 106(5), pp. 997-1032.

Sinn, H.-W., 1996, “Social Insurance, Incentives and Risk Taking”, International Tax and Public Finance, 3, pp. 259-280.

, 2000, "The Threat to the German Welfare State”, CESifo Working Paper no. 320, Munich.

Statistics Sweden, www.scb.se

Taylor-Gooby, P., 1996, “The United Kingdom: Radical Departures and Political

Consensus", in V. George and P. Taylor-Gooby (eds.), Squaring the Welfare Circle, London: Macmillan, pp. 95-116.

Tinbergen, J., 1975, Income Distribution, Amsterdam: North Holland.

Tullock, G. 1959, “Some Problems of Majority Voting”, Journal of Political Economy, 67, 571-79.

United Nations Demographic Yearbook, 1949, 1960, 1997, New York.

U.S. Bureau of the Census, 1998, International Data Base, Washington DC. 
SEMINAR PAPER SERIES

The Series was initiated in 1971. For a complete list of Seminar Papers, please contact the Institute.

1996

616. Assar Lindbeck:

617. Assar Lindbeck:

618. Javier Ortega:

619. Joakim Persson and Bo Malmberg:

620. Assar Lindbeck and Dennis J. Snower:

621. Paul Söderlind and Lars E.O. Svensson:

$\underline{1997}$

622. Assar Lindbeck:

623. John Hassler and José Vicente Rodriguez Mora:

624. Nils-Petter Lagerlöf:

625. Lars E.O. Svensson:

626. James E. Anderson:

627. Mårten Blix:

628. Assar Lindbeck and Dennis J. Snower:

629. Etienne Wasmer:
The West European Employment Problem. 31 pp.

Full Employment and the Welfare State. 22 pp.

How (Good) Immigration Is: A Matching Analysis. $30 \mathrm{pp}$.

Human Capital, Demographics and Growth Across the US States 1920-1990. 21 pp.

Centralized Bargaining, Multi-Tasking, and Work Incentives. 43 pp.

New Techniques to Extract Market Expectations from Financial Instruments. $47 \mathrm{pp}$

Incentives and Social Norms in Household Behavior. $12 \mathrm{pp}$.

Employment Turnover and Unemployment Insurance. $36 \mathrm{pp}$.

Strategic Saving and Non-Negative Gifts. 20 pp.

Inflation Targeting: Some Extensions. 43 pp.

Revenue Neutral Trade Reform with Many Households, Quotas and Tariffs. 36 pp.

Rational Expectations in a VAR with Markov Switching. $37 \mathrm{pp}$.

The Division of Labor Within Firms. 12 pp.

Can Labour Supply Explain the Rise in Unemployment and Inter-Group Wage Inequality in the OECD? 64 pp. 
630. Torsten Persson and Guido Tabellini:

631. John Hassler and Assar Lindbeck:

632. Michael Woodford:

633. Torsten Persson, Gérard Roland and Guido Tabellini:

634. Johan Stennek:

$\underline{1998}$

635. John Hassler and José V. Rodríguez Mora:

636. Jon Faust and Lars E. O. Svensson:

637. Glenn D. Rudebusch and Lars E. O. Svensson:

638. Lars E. O. Svensson:

639. Lars Calmfors:

640. Assar Lindbeck:

641. Donald Brash:

642. Claes Berg and Lars Jonung:

643. Jürgen von Hagen:

644. Bennett T. Mc Callum and Edward Nelson:

645. Assar Lindbeck:

646. Lars E.O. Svensson:
Political Economics and Macroeconomic Policy.100 pp.

Intergenerational Risk Sharing, Stability and Optimality of Alternative Pension Systems. 38 pp.

Doing Without Money: Controlling Inflation in a Post-Monetary World. 62 pp.

Comparative Politics and Public Finance. 55 pp.

Coordination in Oligopoly. $14 \mathrm{pp}$.

IQ, Social Mobility and Growth. 34 pp.

Transparency and Credibility: Monetary Policy with Unobservable Goals. 40 pp.

Policy Rules for Inflation Targeting. 51 pp.

Open-Economy Inflation Targeting. 51 pp.

Unemployment, Labour-Market Reform and Monetary Union. $35 \mathrm{pp}$

Swedish Lessons for Post-Socialist Countries. 37 pp.

Inflation Targeting in New Zealand: Experience and Practice. $11 \mathrm{pp}$.

Pioneering Price Level Targeting: The Swedish

Experience 1931-1937. 50 pp.

Money Growth Targeting. 34 pp.

Nominal Income Targeting in an Open-Economy Optimizing Model. 48 pp.

Swedish Lessons for Post-Socialist Countries. $42 \mathrm{pp}$.

Inflation Targeting as a Monetary Policy Rule. $51 \mathrm{pp}$. 
647. Jonas Agell and Mats Persson:

648. Frederic S. Mishkin:

649. John B. Taylor:

650. Christopher J. Erceg, Dale W. Henderson and Andrew T. Levin:

651. Etienne Wasmer:

652. Daron Acemoglu and Fabrizio Zilibotti:

653. Argia Sbordone:

654. Martin Flodén and Jesper Lindé:

655. Thomas $P$. Tangerås:

656. Peter Svedberg:

657. Lars Calmfors:

658. Torsten Persson and Guido Tabellini:

659. Lars Calmfors:

660. Daron Acemoglu and Fabrizio Zilibotti:

661. Ramon Marimon and Fabrizio Zilibotti:

662. Yves Zenou:
Tax Arbitrage and Labor Supply. 35 pp.

International Experiences With Different Monetary Policy Regimes. 47 pp.

The Robustness and Efficiency of Monetary Policy Rules as Guidelines for Interest Rate Setting by The European Central Bank. 39 pp.

Tradeoffs Between Inflation and Output-Gap Variances in an Optimizing-Agent Model. 43 pp.

Labor Supply Dynamics, Unemployment and Human Capital Investments. 36 pp.

Information Accumulation in Development. 43 pp.

Prices and Unit Labor Costs: A New Test of Price Stickiness. 33 pp.

Idiosyncratic Risk in the U.S. and Sweden: Is there a Role for Government Insurance? 30 pp.

On the Role of Public Opinion Polls in Political Competition. 36 pp.

841 Million Undernourished? On the Tyranny of Deriving a Number. 39 pp.

Macroeconomic Policy, Wage Setting and Employment What Difference Does the EMU Make? 52 pp.

The Size and Scope of Government: Comparative Politics with Rational Politicians. 47 pp.

Monetary Union and Precautionary Labour-Market Reform. $10 \mathrm{pp}$.

Productivity Differences. 48 pp.

Unemployment vs. Mismatch of Talents: Reconsidering Unemployment Benefits. 35 pp.

Urban Unemployment and City Formation. Theory and Policy Implications. $35 \mathrm{pp}$. 
663. Stefan Palmqvist:

664. Kjetil Storesletten:

665: John Hassler, José V. Rodríguez Mora, Kjetil Storesletten and Fabrizio Zilibotti:

1999

666. Michael Woodford:

667. Lars E.O. Svensson:

668. Assar Lindbeck:

669. Lars E.O. Svensson:

670. Assar Lindbeck and Solveig Wikström:

671. Lars E.O. Svensson:

672. Glenn Rudebusch and Lars E.O. Svensson:

673. Lars Svensson:

674. Thomas P. Tangerås:

675. Bertil Ohlin:

676. Assar Lindbeck:

677. Assar Lindbeck and Solveig Wikström:

678. Andrew K. Rose:

679. Jonas Agell, Mats Persson and Hans Sacklén:
Why Central Banks Announce Their Objectives: Monetary Policy with Discretionary Signalling. 22 pp.

Sustaining Fiscal Policy Through Immigration. 41 pp.

Equilibrium Unemployment Insurance. 56 pp.

Optimal Monetary Policy Inertia. 112 pp.

Monetary Policy Issues for the Eurosystem. 54 pp.

The Price in Economic Sciences In Memory of Alfred Nobel 1969-1998. 28 pp.

The Equilibrium Degree of Transparency and Control in Monetary Policy. 25 pp.

The ICT Revolution in Consumer Product Markets. 23 pp.

Does the $P^{*}$ Model Provide Any Rationale for Monetary Targeting? $14 \mathrm{pp}$.

Eurosystem Monetary Targeting: Lessons from U.S. Data. 29 pp.

Price Stability as a Target for Monetary Policy Defining and Maintaining Price Stability. 50 pp.

Collusion-Proof Yardstick Competition. 33 pp.

The Theory of Interregional Exchange. 42 pp.

Unemployment - Structural. 16 pp.

ICT and Household-Firm Relations. 23 pp.

One Money, One Market: Estimating the Effect of Common Currencies on Trade. 40 pp.

Labor Supply Prediction When Tax Avoidance Matters. $36 \mathrm{pp}$. 
680. Lars E.O. Svensson:

$\underline{2000}$

681. Lars E.O. Svensson:

682. Jonas Agell and Mats Persson:

683. Harry Flam and Per Jansson:

684. Harry Flam and M. June Flanders:

685. Assar Lindbeck:

686. Mats Persson:

687. Lars E.O. Svensson:

688. Lars E.O. Svensson and Michael Woodford:

$\underline{2001}$

689. Lars E.O. Svensson and Michael Woodford:

690. Lars Calmfors

691. Assar Lindbeck and Sten Nyberg

692. Lars Calmfors and Asa Johansson

693. Peter Svedberg

694. Assar Lindbeck
How Should Monetary Policy Be Conducted in an Era of Price Stability? 50 pp.

The First Year of the Eurosystem: Inflation Targeting or Not? $11 \mathrm{pp}$

On the Analytics of the Dynamic Laffer Curve. 25pp.

EMU Effects on International Trade and Investment. 42 pp.

The Young Ohlin on the Theory of "Interregional and International Trade". $18 \mathrm{pp}$.

Pensions and Contemporary Socioeconomic Change. 27 pp.

Five Fallacies in the Social Security Debate. 16 pp.

The Zero Bound in an Open Economy: A Foolproof Way of Escaping from a Liquidity Trap. $44 \mathrm{pp}$.

Indicator Variables for Optimal Policy. 43 pp.

Indicator Variables for Optimal Policy under Assymetric Information. $28 \mathrm{pp}$.

Wages and Wage-Bargaining Institutions in the EMU - A Survey of the Issues. $36 \mathrm{pp}$.

Raising Children to Work Hard: Altruism, Work Norms and Social Insurance. 37 pp.

Unemployment Benefits, Contract Length and Nominal Wage Flexibility. 36 pp.

Undernutrition Overestimated. $38 \mathrm{pp}$.

Changing Tides for the Welfare State. $36 \mathrm{pp}$. 
ISSN 0347-8769

Stockholm, 2001

Institute for International Economic Studies 